\title{
Influence of the Addition of Flavoring on the Sodium Content of Fried Potato Chips and the Fatty Acid Profile
}

\author{
Paula Fernandes Montanher ${ }^{1}$, Luana Nascimento de Paula ${ }^{2}$, Fabio Augusto Garcia Coró ${ }^{2}$, \\ Lucia Felicidade Dias ${ }^{2}$, Myka Reghiany Pedrão ${ }^{2}$, Nilson Eve lazio de Souza, ${ }^{2, *}$ \\ ${ }^{1}$ Department of Chemistry, State University of Maringá, Av. Colombo, 5790, CEP 87020-900, Paraná State, Brazil \\ ${ }^{2}$ Federal Technologic University of Parana, Av. Dos Pioneiros, 3131, CEP 86036-370, Londrina, Parana State, Brazil
}

\begin{abstract}
The influence of the addition of flavorings on the sodium content and the fatty acid profile of fried potato chips, particularly of trans fatty acids and the centesimal composition, of fried potato chips was investigated. Three brands of two types of flavored fried potato chips (onion plus parsley and barbecue) and the traditional product were assessed. An increase in the sodium content was observed in all flavored products of all brands. Among the flavored products, brand B had the

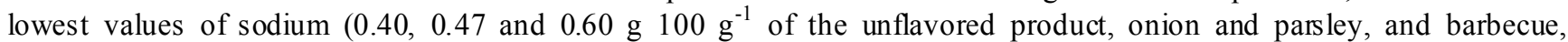
respectively). The total lip id (TL) values were high, ranging from 28 to $35 \%$. All flavors of brand C had the lowest TL content. The fatty acids in the greatest amounts were palmitic acid (16:0), stearic acid (18:0), and oleic acid (18:2n-6). The amounts of trans fatty acids (TFA) were low and under $0.2 \mathrm{~g}$ per portion, the limit set by the regulation in force. A mong the samples

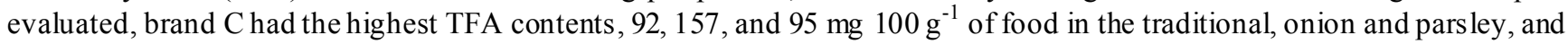
barbecue flavorings, respectively.
\end{abstract}

Keywo rds Fried Potato Chips, Trans Fatty Acids, Flavorings, Sodium

\section{Introduction}

One of the effects of globalization is undoubtedly new eating habits. More and more often industries are investing in ready or easy-to-prepare foods, to which significant amounts of sugar, salt, fat, food dyes, and flavorings are frequently added[1].

Eating Fried potato chips, one of the ready foods with great acceptability, is one of these new eating habits. Two of the negative effects of the excessive consumption of fried potato chips are their high fat and sodium contents.

Sodium is the main cation in the extracellular fluid and one of the main minerals in the plasma. Its function is mainly modulating the liquid exchange between several body compartments. It is also essential for the maintenance of the osmotic pressure of the blood, plasma and fluids. However, excessive consumption of sodium is related to the development of arterial hypertension, one of the major diseases of modern society [2, 3].

Excessive amounts of sodium are used by the food industry, very often to set off the loss of flavor due to the reduction of the fat content[4].

* Corresponding author:

nesouza@ut fpr.edu.br (Nilson Evelazio de Souza)

Published online at http://journal.sapub.org/fph

Copyright (C) 2012 Scientific \& Academic Publishing. All Rights Reserved
Besides the salt added to fried potato chips, flavorings may also be used to add flavor and sharpen and/or modify the flavor and aroma of foods. Besides flavor enhancers, such as monosodium g lutamate, an amino acid naturally present in foods rich in proteins, and one of the main components responsible for the Umami flavor sensation, which is considered the fifth flavour, are also largely used[5].

While salt and aromas are intentionally added to the product, the high fat contents of fried potato chips result from the frying food processing. This processing involves simu ltaneous heat and mass transfer. The medium used in the heat transfer (oil or fat) becomes part of the product. The frying conditions determine the distribution of oil, the texture, and the characteristic final flavor of the food[6].

The oils and fats used in the frying process can undergo degradation reactions associated with the food moisture (hydrolytic reactions), the presence of oxygen (oxidative reactions), and heat (thermal reactions). These reactions lead to the formation of various products, many of which have deleterious effects on human health, such as the trans fatty acids (TFA)[7].

The objective of this study was to investigate the fatty acid composition of fried potato chips and the influence of the addition of flavorings on their sodium content.

\section{Materials and Methods}


Three brands of potato chip were analyzed. Two, labeled $\mathrm{A}$ and $\mathrm{C}$, are sold worldwide, and B is a Brazilian brand. The samples were purchased in local supermarkets between November 2009 and March 2010. Three flavors of each brand were analyzed in three lots with three units of each flavor. The three units of each lot were pooled and analy zed in triplicate. The packages of brands A and B had $100 \mathrm{~g}$ and brand $\mathrm{C}$ had $40 \mathrm{~g}$.

The total lipids (TL) were extracted following the method published by Bligh and Dyer[8] and the fatty acid methyl esters were prepared by the Hartman and Lago method[9].

The fatty acids methyl ester were analyzed in gas chromatograph CP-3380 (Varian, USA) equipped with a flame ionization detection (FID) and a 100\% cyanopropyl bonded silica capillary co lu mn CP-7420 (100 m, 0.25 mm i.d. and $0.25 \mu \mathrm{m}$ film thickness) (Varian, USA). The gas flow rates used were $1.4 \mathrm{~mL} \cdot \mathrm{min}^{-1}$ for the carrier gas $\left(\mathrm{H}_{2}\right) ; 30$ $\mathrm{mL} \cdot \mathrm{min}^{-1}$ for the au xiliary gas $\left(\mathrm{N}_{2}\right)$, and 30 and $300 \mathrm{~mL} \cdot \mathrm{min}^{-1}$ for $\mathrm{H}_{2}$ and the flame synthetic air, respectively. The sample split rate was $1 / 80$. The injector and detector temperatures were $240^{\circ} \mathrm{C}$. The column temperature was kept

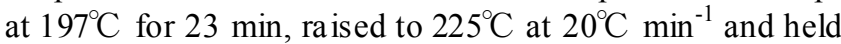
for $15 \mathrm{~min}$.

The column conditions were optimized by Martin et al.[10] for the separation of trans fatty acid methyl esters.

The injections of $2-\mu \mathrm{L}$ volumes were performed in duplicate. The peak areas were determined with the software Workstation version 5.0 (Varian).

The fatty acid methylesters were identified by co mparison with the retention time of standards from Sigma (USA) and by spiking with standards for verification of the increase in the peak areas.

The fatty acid methyl esters were quantified in relation to the internal standard, methyl tricosanoate (23:0) from Sig ma (USA). The quantities of the fatty acids in the samples were calculated using the equation proposed by Joseph and Ackman[11].

$$
\mathrm{MX}=\frac{A_{X} \cdot M p \cdot F_{C T}}{A_{P} \cdot M_{A} \cdot F_{C E A}}
$$

where:

$\mathrm{M}_{\mathrm{x}}=$ Mass of fatty acid $\mathrm{X}$ in $\mathrm{mg} \mathrm{g}^{-1}$ of lipids.

$M_{P}=$ Mass of the internal standard in milligrams.

$\mathrm{M}_{\mathrm{A}}=$ Mass of the sample in grams.

$\mathrm{A}_{\mathrm{X}}=$ Area of fatty acid $\mathrm{X}$.

$A_{P}=$ Area of the internal standard.

$\mathrm{F}_{\mathrm{CT}}=$ Theoretical correction factor.

$\mathrm{F}_{\mathrm{CEA}}=$ Factor of conversion of fatty acid methyl esters.

The moisture, ash, and crude protein content of the samples were determined by the AOAC method[12].

The samples were opened for the analysis of sodium by dry path and the readings were performed with a flame photometer from Analy zer $®$.

\subsection{Statistical analys is}

The results were submitted to variance analys is (ANOVA) at 5\% level of significance using Tukey's test in the software Statistica, version 7.0[13].

\section{Results and Discussion}

The contents of sodium found in fried potato chips are given in Table 1. It ranged from 0.40 to $0.76 \mathrm{~g}$ per $100 \mathrm{~g}$ of product. All three brands presented significant differences $(\mathrm{P}<0.05)$ in sodium contents for the addition of flavorings.

The increase in the amount of sodium in the flavored fried potato chips is related to the addition of flavor enhancers (monosodium glutamate, disodium inosinate, and disodium guanylate), which results in an increase in the salinity of the products[5]. The Brazilian regulations allow the use of food flavor enhancers [14] and set no limit to the amounts added. Amounts are added according to the flavor wanted.

Table 1. Sodium cont ent in fried potato chips in $\mathrm{g}$ per $100 \mathrm{~g}$ of product

\begin{tabular}{cccc}
\hline & Traditional & $\begin{array}{c}\text { Onion and } \\
\text { parsley }\end{array}$ & Barbecue \\
\hline A & $0.58^{\mathrm{a}} \pm 0.109$ & $0.73^{\mathrm{b}} \pm 0.033$ & $0.68^{\mathrm{b}} \pm 0.033$ \\
& & & \\
B & $0.40^{\mathrm{a}} \pm$ & $0.47^{\mathrm{a}} \pm$ & $0.60^{\mathrm{b}} \pm 0.047$ \\
& 0.002 & 0.069 & \\
& & & \\
C & $0.54^{\mathrm{a}} \pm$ & $0.76^{\mathrm{b}} \pm 0.004$ & $0.63^{\mathrm{c}} \pm 0.045$ \\
& 0.007 & & \\
\hline
\end{tabular}

Results are mean \pm standard deviation of triplicate analyses of three lots $(n=9)$. Different letters in the same line indicate significant difference by Tukey's test at $5 \%$ level

According to the World Health Organization[15], the recommended daily intake of sodium is $2 \mathrm{~g}$ (equivalent to $5 \mathrm{~g}$ of salt) for non-hypertensive individuals; for hypertensive individuals the recommended limit is $1 \mathrm{~g}$ of sodium per day.

Taking into consideration the WHO recommended values, the consumption of $100 \mathrm{~g}$ of the Brand $\mathrm{C}$ product

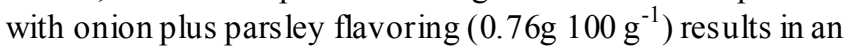
intake very close to the daily limit for hypertensive individuals.

Table 2 gives the centesimal composition results of fried potato chips. The high amounts of total lipids, ranging from

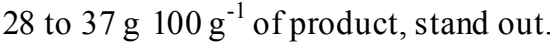

The results of the quantification of fatty acids in fried potato chips are given in Table 3,4 and 5. The statistical analyses of the lots of all samples show a significant difference $(p<0.05)$ in most fatty acids, which indicates the non homogeneity between the lots and standard deviation.

Various factors may lead to the formation of trans fatty acids, including high processing temperature during the oil deodorization and long processing time and high temperature during food frying $[16,17]$.

According to the product nutritional labels of all flavored fried potato chips investigated, they are irradiated for improved food conservation. Research indicates that irradiation may also lead to the formation of trans fatty acids[18]. 
Table 2. Proximal composition of fried potato chips

\begin{tabular}{|c|c|c|c|c|c|c|c|}
\hline Flavoring & Brand & Total Lipids & Protein & Moisture & Ash & Carbohydrates & Calories \\
\hline \multirow{3}{*}{ Traditional } & $\mathrm{A}$ & $33.93 a \pm 0.722$ & $8.13 \mathrm{a} \pm 0.450$ & $1.69 \pm 0.051$ & $4.20 \pm 0.300$ & $52.05 \mathrm{a} \pm 1.300$ & $546.09 \mathrm{a} \pm 7.146$ \\
\hline & $\mathrm{B}$ & $33.32 \pm 1.574$ & $7.93^{\mathrm{a}} \pm 0.594$ & $1.22 \pm 0.164$ & $3.78 \pm 0.168$ & $54.85 \pm 2.504$ & $547.28 \pm 7.839$ \\
\hline & $\mathrm{C}$ & $29.39 \pm 0.335$ & $6.15^{\mathrm{a}} \pm 0.438$ & $2.24^{\mathrm{a}} \pm 0.072$ & $3.16^{\mathrm{a}} \pm 0.074$ & $58.84 \pm 0.535$ & $526.40^{\mathrm{a}} \pm 2.506$ \\
\hline \multirow{3}{*}{$\begin{array}{c}\text { Onion and } \\
\text { Parsley }\end{array}$} & $\mathrm{A}$ & $34.47 \mathrm{a} \pm 1.023$ & $8.47^{\mathrm{a}} \pm 0.226$ & $1.97 \pm 0.095$ & $4.40 \pm 0.017^{\mathrm{a}}$ & $50.69 \mathrm{ab} \pm 1.745$ & $546.87 \mathrm{ab} \pm 6.654$ \\
\hline & $\mathrm{B}$ & $33.05 \pm 0.300$ & $5.33 b \pm 0.219$ & $1.20 \pm 0.039$ & $3.95 \pm 0.180$ & $56.46 \pm 0.422$ & $544.67 \pm 2.329$ \\
\hline & $\mathrm{C}$ & $30.33 \pm 1.078$ & $5.80^{\mathrm{a}} \pm 0.192$ & $2.00 \mathrm{~b} \pm 0.110$ & $3.02^{\mathrm{a}} \pm 0.169$ & $58.76 \pm 1.113$ & $532.16^{\mathrm{a}} \pm 6.25$ \\
\hline \multirow{3}{*}{ Barbecue } & $\mathrm{A}$ & $36.67 \mathrm{~b} \pm 0.815$ & $5.95 b \pm 0.241$ & $1.90 \pm 0.079$ & $4.00 \pm 0.403$ & $51.48 \mathrm{~b} \pm 1.108$ & $559.75 \mathrm{~b} \pm 4.010$ \\
\hline & $\mathrm{B}$ & $33.92 \pm 0.143$ & $5.49 b \pm 0.361$ & $1.76 \pm 0.393$ & $4.14 \pm 0.407$ & $54.81 \pm 1.960$ & $545.62 \pm 9.068$ \\
\hline & $\mathrm{C}$ & $28.13 \pm 1.927$ & $5.00 \mathrm{~b} \pm 0.076$ & $2.30^{\mathrm{a}} \pm 0.037$ & $4.32 b \pm 0.226$ & $60.60 \pm 1.136$ & $512.88 \mathrm{~b} \pm 8.232$ \\
\hline
\end{tabular}

Results are mean \pm standard deviation of triplicate analyses of three lots $(n=9)$. Different letters in the same line indicate significant difference by Tukey's test at $5 \%$ level

Table 3. Fatty acid contents (mg $\left.100 \mathrm{~g}^{-1}\right)$ of three brands of traditional flavor fried potato chips

\begin{tabular}{|c|c|c|c|}
\hline \multirow{2}{*}{ Fatty acids } & \multicolumn{3}{|c|}{ Traditional } \\
\hline & Brand A & Brand B & Brand C \\
\hline $12: 0$ & $75 \pm 3$ & $91 \pm 39$ & $53 \pm 3$ \\
\hline $14: 0$ & $226 \pm 35$ & $279 \pm 69$ & $174 \pm 8$ \\
\hline $15: 0$ & $12 \mathrm{ab} \pm 2$ & $14 b \pm 1$ & $9^{a} \pm 2$ \\
\hline $16: 0$ & $13091^{a} \pm 637$ & $14847^{\mathrm{a}} \pm 1099$ & $8250 b \pm 191$ \\
\hline $16: \ln -9$ & $9 \pm 1$ & $9 \pm 1$ & $8 \pm 2$ \\
\hline $16: \ln -7$ & $30 \pm 6$ & $37 \pm 9$ & $34 \pm 4$ \\
\hline $17: 0$ & $27^{\mathrm{a}} \pm 2$ & $32^{\mathrm{a}} \pm 4$ & $19 b \pm 0$ \\
\hline $18: 0$ & $1637^{\mathrm{a}} \pm 55$ & $1824^{\mathrm{a}} \pm 159$ & $114 b \pm 109$ \\
\hline $18: 1 \mathrm{t} 9$ & $19 \pm 3$ & $26 \pm 2$ & $18 \pm 5$ \\
\hline $18: \ln -9$ & $12477 \pm 410$ & $13305 \pm 736$ & $12908 \pm 90$ \\
\hline $18: \ln -7$ & $302 \pm 91$ & $343 \pm 57$ & $313 \pm 70$ \\
\hline $18: 2 \mathrm{c} 9, \mathrm{t} 12$ & $24^{\mathrm{a}} \pm 2$ & $26^{a} \pm 4$ & $33 b \pm 1$ \\
\hline $18: 2 \mathrm{t} 9, \mathrm{cl} 2$ & $22 \mathrm{a} \pm 1$ & $23^{\mathrm{a}} \pm 3$ & $29 \mathrm{~b} \pm 0$ \\
\hline $18: 2 n-6$ & $2756 \pm 336$ & $2875 \pm 507$ & $3954 \pm 378$ \\
\hline $18: 3 \mathrm{t} 9, \mathrm{c} 12, \mathrm{t} 15$ & $6 \pm 1$ & $\mathrm{dq}^{* *}$ & $7 \pm 0$ \\
\hline$*$ & $5 \pm 2$ & $\mathrm{dq}^{* *}$ & $4 \pm 0$ \\
\hline $18: 3 n-3$ & $65 \pm 19$ & $64 \pm 20$ & $45 \pm 10$ \\
\hline $20: 0$ & $125 \mathrm{ab} \pm 13$ & $138^{\mathrm{a}} \pm 12$ & $94 b \pm 12$ \\
\hline $20: \ln -9$ & $42 \pm 1$ & $43 \pm 2$ & $41 \pm 2$ \\
\hline $22: 0$ & $22^{\mathrm{a}} \pm 3$ & $24^{\mathrm{a}} \pm 2$ & $79 b \pm 13$ \\
\hline $24: 0$ & $25^{\mathrm{a}} \pm 4$ & $27 \mathrm{ab} \pm 4$ & $37 b \pm 5$ \\
\hline$\overline{\Sigma S F A}$ & $15240^{a} \pm 640$ & $17278^{a} \pm 1113$ & $9856 b \pm 221$ \\
\hline ¿PUFA & $2820^{\mathrm{a}} \pm 336$ & $2939 \mathrm{ab} \pm 507$ & $3999 b \pm 378$ \\
\hline$\Sigma$ MUFA & $12860 \pm 93$ & $13738 \pm 738$ & $13305 \pm 114$ \\
\hline$\Sigma \mathrm{TFA}$ & $76^{\mathrm{a}} \pm 4$ & $76^{\mathrm{a}} \pm 5$ & $92 b \pm 5$ \\
\hline$n-6$ & $2756^{a} \pm 336$ & $2875^{\mathrm{a}} \pm 507$ & $3954 b \pm 378$ \\
\hline$n-3$ & $65 \pm 19$ & $63 \pm 20$ & $45 \pm 10$ \\
\hline$n-6 / n-3$ & $44^{\mathrm{a}} \pm 14$ & $46^{a} \pm 17$ & $90 b \pm 21$ \\
\hline
\end{tabular}

Results are mean \pm standard deviation of triplicate analyses of three lots $(n=9)$. Different letters in the same line indicate significant difference by Tukey's test at $5 \%$ level. *Isomers $(18: 3 \mathrm{t} 9, \mathrm{c} 12, \mathrm{c} 15$ and $\mathrm{c} 9, \mathrm{t} 12, \mathrm{c} 15)$ of LNA ** dq: detected but not quantified. SFA: saturated fatty acids, MUFA: monounsaturated fatty acids, PUFA: polyunsaturated fatty acids, TFA: trans fatty acids. n- $6=$ omega- 6 fatty acids, n-3: omega-3 fatty acids 
Table 4. Fatty acid contents $\left(\mathrm{mg} 100 \mathrm{~g}^{-1}\right)$ of three brands of onion and parsley flavored fried potato chips

\begin{tabular}{|c|c|c|c|}
\hline \multirow{2}{*}{ Fatty acids } & \multicolumn{3}{|c|}{ Onion and Parsley } \\
\hline & Brand A & Brand B & Brand C \\
\hline $12: 0$ & $139 \pm 39$ & $112 \pm 18$ & $80 \pm 4$ \\
\hline $14: 0$ & $218^{\mathrm{ab}} \pm 21$ & $252^{\mathrm{a}} \pm 11$ & $215^{\mathrm{b}} \pm 7$ \\
\hline $15: 0$ & $12^{\mathrm{a}} \pm 2$ & $15^{\mathrm{b}} \pm 2$ & $10^{\mathrm{a}} \pm 1$ \\
\hline $16: 0$ & $12767^{a} \pm 453$ & $13147^{\mathrm{a}} \pm 799$ & $8305^{b} \pm 344$ \\
\hline $16: \ln -9$ & $7^{\mathrm{a}} \pm 1$ & $9^{b} \pm 1$ & $7^{\mathrm{a}} \pm 0$ \\
\hline $16: \ln -7$ & $27^{\mathrm{a}} \pm 2$ & $35^{\mathrm{b}} \pm 4$ & $38^{\mathrm{b}} \pm 2$ \\
\hline $17: 0$ & $22^{\mathrm{a}} \pm 2$ & $23^{\mathrm{a}} \pm 1$ & $16^{\mathrm{b}} \pm 1$ \\
\hline $18: 0$ & $1610^{\mathrm{a}} \pm 53$ & $1365^{\mathrm{b}} \pm 38$ & $1057^{\mathrm{c}} \pm 32$ \\
\hline $18: 1 \mathrm{t} 9$ & $14^{\mathrm{a}} \pm 4$ & $23^{\mathrm{b}} \pm 2$ & $82^{c} \pm 3$ \\
\hline $18: \ln -9$ & $12405 \pm 302$ & $12790 \pm 794$ & $12546 \pm 472$ \\
\hline $18: \ln -7$ & $953 \pm 354$ & $1280 \pm 131$ & $1237 \pm 98$ \\
\hline $18: 2 \mathrm{c} 9, \mathrm{t} 12$ & $18^{\mathrm{a}} \pm 2$ & $24^{\mathrm{b}} \pm 8$ & $35^{\mathrm{b}} \pm 0$ \\
\hline $18: 2 \mathrm{t} 9, \mathrm{cl} 2$ & $15^{\mathrm{a}} \pm 1$ & $20^{\mathrm{b}} \pm 8$ & $30^{\mathrm{b}} \pm 0$ \\
\hline $18: 2 n-6$ & $2886^{\mathrm{a}} \pm 74$ & $2849^{a} \pm 209$ & $4474^{b} \pm 186$ \\
\hline $18: 3 \mathrm{t} 9, \mathrm{c} 12, \mathrm{t} 15$ & $5 \pm 1$ & $\mathrm{dq}^{* *}$ & $6 \pm 0$ \\
\hline$*$ & $4 \pm 1$ & $\mathrm{dq}^{* *}$ & $5 \pm 0$ \\
\hline $18: 3 n-3$ & $62^{\mathrm{a}} \pm 2$ & $73^{\mathrm{b}} \pm 4$ & $50^{\mathrm{c}} \pm 1$ \\
\hline $20: 0$ & $121^{\mathrm{a}} \pm 5$ & $92^{\mathrm{b}} \pm 0$ & $67^{\mathrm{c}} \pm 2$ \\
\hline $20: \ln -9$ & $42^{\mathrm{a}} \pm 1$ & $36^{\mathrm{b}} \pm 3$ & $34^{\mathrm{b}} \pm 0$ \\
\hline $22: 0$ & $22^{\mathrm{a}} \pm 1$ & $17^{\mathrm{b}} \pm 1$ & $62^{\mathrm{c}} \pm 2$ \\
\hline $24: 0$ & $24^{\mathrm{a}} \pm 2$ & $14^{\mathrm{b}} \pm 1$ & $29^{\mathrm{c}} \pm 1$ \\
\hline$\Sigma \mathrm{SFA}$ & $14985^{a} \pm 458$ & $15038^{\mathrm{a}} \pm 800$ & $9840^{\mathrm{b}} \pm 345$ \\
\hline$\Sigma$ PUFA & $2949^{a} \pm 74$ & $2922^{\mathrm{a}} \pm 209$ & $4524^{b} \pm 186$ \\
\hline$\Sigma$ MUFA & $13335 \pm 465$ & $14151 \pm 804$ & $13863 \pm 482$ \\
\hline$\Sigma T F A$ & $56^{\mathrm{a}} \pm 8$ & $67^{a} \pm 11$ & $157^{\mathrm{b}} \pm 3$ \\
\hline$n-6$ & $2866^{\mathrm{a}} \pm 74$ & $2849^{a} \pm 209$ & $4474^{b} \pm 186$ \\
\hline$n-3$ & $62^{\mathrm{a}} \pm 2$ & $73^{b} \pm 4$ & $50^{\mathrm{c}} \pm 1$ \\
\hline$n-6 / n-3$ & $46^{\mathrm{a}} \pm 9$ & $39^{a} \pm 3$ & $89^{b} \pm 4$ \\
\hline
\end{tabular}

Results are mean \pm standard deviation of triplicate analyses of three lots $(n=9)$. Different letters in the same line indicate significant difference by Tukey's test at $5 \%$ level. *Isomers $(18: 3 \mathrm{t} 9, \mathrm{c} 12, \mathrm{c} 15$ and $\mathrm{c} 9, \mathrm{t} 12, \mathrm{c} 15)$ of LNA ** dq: detected but not quantified. SFA: saturated fatty acids, MUFA: monounsaturated fatty acids, PUFA: polyunsaturated fatty acids, TFA: trans fatty acids. n- $6=$ omega- 6 fatty acids, n-3: omega-3 fatty acids 
Table 5. Fatty acid contents $\left(\mathrm{mg} 100 \mathrm{~g}^{-1}\right)$ of three brands of barbecue flavored fried potato chips

\begin{tabular}{|c|c|c|c|}
\hline \multirow[b]{2}{*}{ Fatty acids } & \multicolumn{3}{|c|}{ Barbecue } \\
\hline & Brand A & Brand B & Brand C \\
\hline $12: 0$ & $93^{\mathrm{a}} \pm 2$ & $96^{\mathrm{a}} \pm 2$ & $56^{\mathrm{b}} \pm 2$ \\
\hline $14: 0$ & $222 \mathrm{ab} \pm 16$ & $238^{a} \pm 29$ & $173^{\mathrm{b}} \pm 8$ \\
\hline $15: 0$ & $14^{\mathrm{a}} \pm 1$ & $14^{a} \pm 2$ & $8^{b} \pm 0$ \\
\hline $16: 0$ & $13517 a \pm 1331$ & $13530^{a} \pm 1524$ & $7996^{b} \pm 380$ \\
\hline $16: \ln -9$ & $14^{\mathrm{a}} \pm 1$ & $15^{\mathrm{a}} \pm 0$ & $11 b \pm 1$ \\
\hline $18: 0$ & $1465^{\mathrm{a}} \pm 36$ & $1381^{a} \pm 149$ & $906^{\mathrm{a}} \pm 48$ \\
\hline $18: 1 \mathrm{t} 9$ & $24 \pm 3$ & $37 \pm 14$ & $18 \pm 1$ \\
\hline $18: \ln -9$ & $14443^{\mathrm{a}} \pm 605$ & $13397 \mathrm{ab} \pm 358$ & $12245^{b} \pm 632$ \\
\hline $18: \ln -7$ & $252 \pm 22$ & $268 \pm 7$ & $261 \pm 27$ \\
\hline $18: 2 \mathrm{c} 9, \mathrm{t} 12$ & $28^{\mathrm{a}} \pm 1$ & $25^{\mathrm{a}} \pm 1$ & $34^{\mathrm{b}} \pm 2$ \\
\hline$*$ & $9^{a} \pm 0$ & $\mathrm{dq}^{* *}$ & $6^{\mathrm{b}} \pm 1$ \\
\hline $18: 3 n-3$ & $81^{a} \pm 6$ & $66 \mathrm{~b} \pm 4$ & $39^{c} \pm 3$ \\
\hline $20: 0$ & $109^{a} \pm 2$ & $99^{a} \pm 6$ & $68^{\mathrm{b}} \pm 5$ \\
\hline $20: \ln -9$ & $43^{a} \pm 1$ & $39 a \pm 0$ & $33^{b} \pm 3$ \\
\hline $22: 0$ & $24^{\mathrm{a}} \pm 4$ & $25^{a} \pm 6$ & $63^{b} \pm 6$ \\
\hline $24: 0$ & $26 a b \pm 5$ & $19^{\mathrm{a}} \pm 1$ & $29^{b} \pm 2$ \\
\hline$\Sigma$ SFA & $15495^{\mathrm{a}} \pm 1332$ & $15430^{\mathrm{a}} \pm 1531$ & $9316^{b} \pm 383$ \\
\hline ¿PUFA & $3082^{\mathrm{a}} \pm 201$ & $2709^{a} \pm 139$ & $4020^{b} \pm 231$ \\
\hline$\Sigma$ MUFA & $15011^{\mathrm{a}} \pm 605$ & $13759^{\mathrm{ab}} \pm 358$ & $12581^{b} \pm 632$ \\
\hline$\Sigma \mathrm{TFA}$ & $95 \pm 3$ & $85 \pm 14$ & $95 \pm 4$ \\
\hline
\end{tabular}

Results are mean \pm standard deviation of triplicate analyses of three lots $(\mathrm{n}=9)$. Different letters in the same line indicate significant differen ce by Tukey's test at 5\% level. *Isomers (18:3t9,c12,c15 and c9,t12,c15) of LNA ** dq: detected but not quantified. SFA: saturated fatty acids, MUFA: monounsaturated fatty acids, PUFA: polyunsaturated fatty acids, TFA: trans fatty acids. n- $6=$ omega 6 fatty acids, n-3: omega-3 fatty acids

The nutritional labels of the products investigated informed zero contents of trans fatty acids. Foods are considered to have ze ro trans fatty acids when their content is lower or equal to $0.2 \mathrm{~g}$ per helping[19].Thus, the information in the food labels of all products was confirmed, as none presented more than $0.2 \mathrm{~g}$ per portion of $25 \mathrm{~g}$ (label portion size).

The addition of flavorings to fried potato chips was found to be associated with the sodium content, which was high in all the investigated brands.

The total trans fatty acid contents of the three brands of fried potato chips were low and within the regulation values. A trans fatty acid content reduction was also observed over the years, with the consequent improvement of the product. However, due to the large amounts of saturated fatty acids and total lipids in fried potato chips, moderation in their consumption is advisable.

The replacement of hydrogenated vegetable fat resulted in a decrease in trans fatty acids, as demonstrated by the samples analyzed; however, it also increased the saturated fatty acid content.

The $n-6 / n-3$ ratio of all samples was above the literature recommendation, which ranges from $2: 1$ to $3: 1[20$ ] and $5: 1$ to $10: 1[21]$. The current ratio ranged from 39 to 100 , with brand $\mathrm{C}$ presenting the highest values for all flavors.

\section{ACKNOWLEDGEMENTS}

The authors are grateful to CAPES and CNPq for the financial support.

\section{REFERENCES}

[1] Garcia, D., W. R., (2003). Reflexos da globalização na cultura alimentar: Considerações sobre as mudanças na alimentação urbana. Revista de nutrição, 16, 483-492. http://dx.doi.org/10.1590/S1415-52732003000400011

[2] Mark, A. L., Anderson, E. A., (1995). Genetic factors determine the blood pressure response to insulin resistance and hiperinsulinemia: a call to refocus the insulin pothesis of hypertension. Proceedings of Society for Experimental Biology Medicine, 208, $330 \quad-336$. http://apps.webofknowledge.com/full_record.do?product=U A\&search_mode $=$ General Search\&qid $=8 \&$ SID $=3$ AgaoFDpA aAchjpLno $8 \&$ page $=1 \&$ doc $=6$

[3] Boesch, I., (2012) Preferences for Attributes of Industrial Potatoes: An Empirical Investigation of the Swiss Market. American Journal of Potato Research, 89, 199-206. DOI: $10.1007 / \mathrm{s} 12230-012-9244-5$

[4] Champagne, C. M.; Lastor K. C., (2009). Sodium intake: Challenges for researchers attempting to assess consumption relative to health risks. Journal ff Food Composition And Analysis. 22, S19-S22, DOI: 10.1016/j.jfca.2009.01.009

[5] Prescott, J., (2004). Effects of added glutamate on liking for novel food flavors. Appetite, 42, 143-150. DOI: 


\subsection{6/j.appet.2003.08.013}

[6] Rajkumar, V., Moreira, R., Barrufet, M., (2003). Modeling the structural changes of tortilla chips during frying. Journal of Food Engineering. 60, 167-175. DOI: $10.1016 / \mathrm{S} 0260-8774(03) 00037-2$

[7] Choe, E., M in, D. B., (2007) Chemistry of deep-fat fry ing oils. Journal of food Science, 72, 77-86. DOI: 10.1111/j.1750-3841.2007.00352.x

[8] Bligh, E. G., Dyer, W. J., (1959). A rapid method of total lipid extraction and purification. Canadian journal Biochemistry Physiology, 37, 911-917. http://garfield.library.upenn.edu/cla ssics1978/A1978FZ82000002.pdf

[9] Hartman, L., Lago, R. C. A., (1973). Rapid determination of fatty acid methyl esthers from lipids. Laboratory Practice, 22, 475-477.

[10] Martin, C. A., Oliveira, C. C., Visentainer, J. V., Matsushita, M., Souza N. E., (2008). Optimization of the selectivity of a cyanopropyl stationary phase for the gas chromatographic analysis of trans fatty acids, Journal of Chromatography A, 1194, 111-117. DOI: 10.1016/j.chroma.2008.04.033

[11] Joseph, J. D., Ackman, R. G., (1992). Capillary column gas chromatography method for analy sis of encapsulated fish oil and fish oil ethyl esters: collaborative study. Journal of Association of Official Analytical Chemical International, 75 (3), 488-506. http://app s.webofknowledge.com/full record.d $\mathrm{o}$ ?product $=$ UA\&search_mode $=$ GeneralSearch \&qid $=6 \&$ SID $=3$ AgaoFDpAaAchjpLno8\&page $=1 \&$ doc $=1$

[12] Cunnif, P. A., (1998). Official Methods of Analysis of AOAC international (6th Ed.) Arlington: Association of Official Analy tical Chemists.

[13] StaSoft, (2005). Statistica 7.0 software, Tucksa, USA.

[14] ANVISA - Agência Nacional de Vigilância Sanitária.
Resolução - RDC, No 1, de 2 de Janeiro de 2001. http://e-legis.anvisa. gov.br/leisref/public/showAct.php?id=1 290

[15] WHO - World Health Organization. (2003 ). Diet, nutrition and the prevention of chronic diseases. Report of a Joint WHO/ FAO Expert Consultation. Geneva; (WHOTechnical report series, 916).

[16] Martin, C. A., Milinsk, M. C., Visentainer, J. V., Matsushita, M., Souza N. E., (2007). Trans fatty acid-forming processes in foods: a review, Anais da Academia Brasileira de Ciên cia, 79, 343-350. DOI: 10.1590/S0001-37652007000200015

[17] Stroher, G. ; Rodrigues, A. C. ; Gohara, A. K. ; Visentainer, J. V. ; Matshushita, M. ; de Souza, N. E., (2012). Fatty Acid Quantification in different types of cookies with emphasis on trans Fatty Acids. Acta Scientiarum. Technology. 34, 105-110.

[18] Yilmaz, I., Gecgel, U., (2007). Effects of gamma irradiation on trans fatty acid compositionin ground beef. Food Control, 18, 635-638. DOI: 10.1016/j.foodcont.2006.02.009

[19] ANVISA - Agência Nacional de Vigilância Sanitária. Resolução - RDC n 360 de 23 de dezembro de 2003. http://www.anvisa.gov.br/legis/resol/2003/rdc/360_03rdc.ht $\mathrm{m}$.

[20] Simopoulos, A. P. (2002) The importance of the ratio of omega-6/omega-3 essential fatty acids. Biomedicine \& Pharmacotherapy, 56, 365-379. DOI: 10.1016/S0753-3322(0 2)00253-6

[21] WHO - World Health Organization. (1995). Joint Consultation: fats and oils in human nutrition. Nutrition Reviews, 53(7), 202-205. http://apps.webofknowledge.co $\mathrm{m} /$ full record.do?product $=\mathrm{UA} \&$ search mode $=$ GeneralSearc h\&qid=17\&SID=3A gaoFDpAaAchjpLno8\&page $=4 \&$ doc $=3$ 9 